\title{
CHARACTERISATION OF PORPHYROMONAS-PREVOTELLA GROUP ISOLATED FROM ORODENTAL INFECTIONS AND ANTIMICROBIAL ACTION OF HERBAL EXTRACTS
}

\author{
Beena Antony ${ }^{1}$, Chinu Maria Cyriac ${ }^{2}$, Jinsha $K^{3}$, Ramanath Karicheri ${ }^{4}$ \\ 1 Professor, Department of Microbiology, Fr. Muller Medical College, Mangalore. \\ 2 Postgraduate Student, Department of Endodontics and Conservative Dentistry, AJ Institute of Dental Sciences, Mangalore. \\ ${ }^{3}$ Postgraduate Student (M.Sc), Department of Microbiology, School of Health Sciences, Kannur University. \\ ${ }^{4}$ Research Scholar, Fr. Muller Medical College, Mangalore.
}

\begin{abstract}
\section{BACKGROUND}

Porphyromonas-Prevotella group includes non-motile, non-sporing, black pigmented Gram-negative coccobacilli. Even though they are commensals of oral cavity, many species are associated with a variety of orodental as well as invasive human infections. As these isolates are exhibiting resistance to many antibiotics, an attempt is done in this study to evaluate antimicrobial activity of various herbal extracts from natural sources.

Objectives- To characterise Porphyromonas-Prevotella group isolated from orodental infections by biochemical reactions and to screen the antimicrobial action of various herbal extracts against these isolates.
\end{abstract}

\section{MATERIALS \& METHODS}

Clinical samples such as subgingival plaques, paper points, saliva were directly inoculated in Reduced Transport Fluid and Robertson's Cooked Meat Medium, subcultured onto culture media using a semiquantitation technique under anaerobic conditions employing BD GasPak system. After incubation, colonies morphologically resembling Porphyromonas-Prevotella group were speciated by biochemical reactions. Antimicrobial activity was performed against various herbal extracts on supplemented Brucella Blood Agar by Kirby-Bauer disc diffusion method. Seven herbal extracts - Betel leaf, Clove, Ginger, Lemon grass, Mango leaves, Nutmeg, Peppermint were employed in this study.

\section{RESULTS}

Speciation of 43 isolates of Porphyromonas-Prevotella group revealed Porphyromonas gingivalis, Porphyromonas asaccharolytica, Prevotella intermedia, Prevotella melaninogenica and Prevotella buccae. All 43 isolates showed variable activity to the herbal extracts. Among the seven extracts, clove oil, lemongrass oil and nutmeg oil showed good activity. Betel leaf extract was inactive against these isolates while Ginger, Mango leaves and Peppermint showed variable activity.

\section{CONCLUSION}

Porphyromonas-Prevotella group includes important pathogens encountered in orodental infections. The results of this preliminary study is a promising finding for developing an alternate treatment regimen, without side effects, for the control of orodental infections caused by Porphyromonas and Prevotella group.

\section{KEYWORDS}

Porphyromonas-Prevotella Group, Anaerobic Bacteria, Orodental Infections, Antimicrobial Action, Herbal Extracts.

HOW TO CITE THIS ARTICLE: Antony B, Cyriac CM, Jinsha K, et al. Characterisation of Porphyromonas-Prevotella group isolated from orodental infections and antimicrobial action of herbal extracts. J. Evolution Med. Dent. Sci. 2017;6(57):4230-4235, DOI: $10.14260 /$ Jemds/2017/918

\section{BACKGROUND}

Porphyromonas and Prevotella are non-motile non-sporing obligate anaerobic Gram-negative coccobacilli. The main characteristic feature of the group is to form black colonies on Blood agar due to the production of porphyrin pigment.(1) The genus contain non-pigmented species also. Most of the species are commensal flora of oral cavity, upper gastrointestinal tract, respiratory tract and colon.(2) Porphyromonas-Prevotella group is a major pathogen of

Financial or Other, Competing Interest: None.

Submission 12-06-2017, Peer Review 07-07-2017,

Acceptance 12-07-2017, Published 17-07-2017.

Corresponding Author:

Beena Antony,

Professor,

Department of Microbiology,

Fr. Muller Medical College,

Kankanady, Mangalore-575002, Karnataka.

E-mail: beenafmmc@gmail.com

DOI: $10.14260 /$ jemds/2017/918 severe adult periodontitis, a common, progressive disease that affects the supporting structures of the teeth, causing loss of attachment to the bone and often resulting in tooth loss. $(3,4)$ It is also a component of the "red complex" (Consisting of Porphyromonas gingivalis, Treponema denticola, and Tannerella forsythia), a polybacterial pathogenic consortium which is strongly associated with advanced periodontal lesions.(5) Porphyromonas and Prevotella group present as a commensal flora can cause variety of invasive infections such as abscesses, bacteraemia, wound infection, bite infections, genital tract infection.(2) They are also reported to cause acute infections such as maxillary sinusitis associated with dental infections, intraabdominal infections following perforation.(6-9)

In the recent past, Porphyromonas and Prevotella group was found to exhibit resistance to many antibiotics including penicillin, cephalosporin, and tetracycline.(10-12) The increasing prevalence of antimicrobial resistance in these pathogens possess a significant challenge to successful treatment outcome in periodontitis patients. In dentistry, 
chlorhexidine at $0.2 \%$ concentration became the standard international concentration for dental plaque control.(13) However, it has been found to have a number of adverse side effects such as alteration in taste, staining of teeth, restorative material and the dorsum of the tongue, as well as supragingival calculus formation.(14) Use of plant extracts with medicinal properties represents an alternative and better treatment option for periodontitis as reported by some investigators.(15)

In this context, scientists are shifting their attention to herbal medicines without side effects as source of new antimicrobial agents. This search resulted in the discovery of new antibacterial drugs of plant origin which are safe, cheap easily available and are usually devoid of associated risk of chemotherapeutic agents.(16) Numerous medicinal plant extracts or phytochemicals have been shown to inhibit the formation of dental biofilms by reducing the adhesion of microbial pathogens to the tooth surface, which is a primary event in the initiation and the progression to periodontitis. $(17,18)$

In the present study, 43 isolates of PorphyromonasPrevotella group isolated from orodental infections were characterised based on biochemical reactions. Seven herbal extracts which were used in oral care by earlier generation were screened for antimicrobial susceptibility against these isolates. Among these herbal extracts, Clove oil, Lemongrass oil, Nutmeg oil were found to exhibit very active antimicrobial effect against them. To the best of our knowledge, this study appears to be a preliminary one of this kind.

\section{MATERIALS \& METHODS}

The present study is a descriptive and laboratory investigative experimental one conducted in the Department of Microbiology, Father Muller Medical College, Mangaluru. A purposive sampling was employed and the dental samples included in the study were obtained from Dept. of Endodontics \& Conservative Dentistry, AJ Institute of Dental Sciences, Mangaluru. The procedures followed were in accordance with the ethical standards of the Institutional Ethics Committee.

\section{Transport of Samples \& Processing}

Clinical samples such as saliva, subgingival plaque or paper points from orodental infections were directly inoculated into Reduced Transport Fluid (RTF)(19) \& Robertson's Cooked Meat Medium (RCM) and immediately transported to the Department of Microbiology for further processing. Both the media were prepared 'in house' constituting the ingredients mentioned in the composition, which were procured from HiMedia Pvt. Ltd. Mumbai.

RTF was subjected to Vortex mixing for 30 seconds to disperse bacteria and processed immediately to yield a semiquantitative growth. RCM inoculated with the specimen were incubated at $37^{\circ} \mathrm{C}$ for 24 hours, prior to inoculation on to culture media. For the isolation of Porphyromonas and Prevotella group, both RTF \& RCM were subcultured on to Laked blood agar or Lysed BA (LBA), a non-selective medium and Neomycin blood agar (NBA) i.e. BA containing 100 $\mu \mathrm{g} / \mathrm{mL}$ Neomycin, the selective medium for all anaerobes. Both these plating media were prepared 'in house' taking care of the quality control measures. A metronidazole disc (5 $\mu \mathrm{g}$ ) was placed on each medium for the presumptive identification of anaerobes and incubated in Becton and Dickinson (BD) anaerobic jar using GasPak EZ Sachet (Anaerobe gas generating pouch system with indicator) at $37^{\circ} \mathrm{C}$ for 72 hours to a maximum of 1 week.

After incubation characteristic small, smooth, raised black pigmented colonies which showed Gram-negative coccobacilli on Gram stain, yielding a 3+ or 4+ growth on culture media, were included in the study. These colonies were presumptively identified as Porphyromonas or Prevotella group and were speciated by antibacterial sensitivity to $5 \mu \mathrm{g}$ vancomycin disc, biochemical reactions such as indole, fermentation of carbohydrates such as glucose, lactose, sucrose, maltose and esculin hydrolysis according to the standard procedures.(20,21) Two nonpigmented isolates showing characteristic reactions were subjected to Crystal Identification system (BD) and identified as Prevotella buccae. A plate containing strict aerobe and strict anaerobe with a metronidazole disc in the centre was included as a biological control every time. ATCC Porphyromonas gingivalis 33277 was employed in parallel for the characterisation and antimicrobial susceptibility testing along with clinical strains.

\section{Antimicrobial Action against Herbal Extracts}

Once the species identification of Porphyromonas and Prevotella was completed, colonies were subjected to screening of antimicrobial action against herbal extracts on Brucella Blood Agar in an anaerobic environment by disc diffusion method. Seven herbal extracts used in traditional medicine for the control of orodental infections were employed in the study- Extracts of Betel leaf, Mango leaves and essential oils of Clove, Ginger, Lemongrass, Nutmeg and Peppermint.

\section{Preparation of Extracts \& Essential Oils}

The alcoholic extracts of Betel leaf, Mango leaves were prepared by simple maceration procedure. Leaves were washed, dried and aseptically sliced. $100 \mathrm{~g}$ of the substance was added to $500 \mathrm{~mL}$ of the $70 \%$ ethyl alcohol, allowed to stand at room temperature for a period of 24 hours with frequent agitation in a mechanical shaker. The filtrate was collected, the solvent was evaporated at $60^{\circ} \mathrm{C}$ in a water bath and the sterility was confirmed.

Essential oils of Clove, Ginger, Lemongrass, Nutmeg and Peppermint were extracted by Neo-Clevenger's method using Clevenger's apparatus using $100 \mathrm{~g}$ of coarse powder of each plant part in $60 \mathrm{~mL}$ glycerol and $300 \mathrm{~mL}$ of distilled water with a mantle temp. set to $90^{\circ} \mathrm{C}$ for 8 hours. The essential oil was separated by drying using saturated sodium chloride, dichloromethane and anhydrous sodium sulphate. The preparation of the essential oils was carried out in the Department of Pharmacognosy, Manipal College of Pharmaceutical Sciences, Manipal University,

\section{Procedure for Disc Diffusion Testing}

In order to test the efficacy of various herbal extracts, the test was performed by disc diffusion technique as follows.(22) Porphyromonas and Prevotella were grown in Viande Levure broth(21) and turbidity was adjusted to $0.5 \%$ McFarland standard. By using this suspension, a lawn culture of bacteria was made on the surface of Brucella blood agar,(20) then the filter paper discs impregnated with appropriate 
concentration of herbal extracts were placed on the lawn culture. The plates were incubated under strict anaerobic condition for 72 hours and examined for the zones of inhibition which corresponds to the degree of sensitivity of the antimicrobial agent.

\section{RESULTS}

A total of 43 isolates of Porphyromonas and Prevotella group were included in the study and among these Porphyromonas gingivalis was the most common isolate (46.5\%). The distribution of different species obtained in the study is given in the Table 1. All these isolates were characterised based on biochemical reactions and sensitivity to vancomycin. Biochemical characterisation of the isolates is shown in the Table 2.

Table 3 describes the nine plants employed in the study, their common names, scientific names, parts used for the preparation of the extracts and the Phytochemicals present in them. All the 43 isolates were subjected to disc diffusion method for the demonstration of the antimicrobial action of seven herbal extracts. Among these seven herbals, Clove oil, Lemongrass oil, Nutmeg oil showed maximum activity. Details are shown in the Table 4. Betel leaf extract was inactive against all the 43 isolates while Ginger, Mango leaves and Peppermint extracts showed variable activity. Table 5.

\begin{tabular}{|c|c|c|c|}
\hline No. & Isolates & $\begin{array}{c}\text { No. of } \\
\text { Isolates }\end{array}$ & $\%$ \\
\hline 1 & Porphyromonas gingivalis & 20 & 46.5 \\
\hline 2 & Porphyromonas asaccharolytica & 5 & 11.6 \\
\hline 3 & Prevotella intermedia & 9 & 20.9 \\
\hline 4 & Prevotella melaninogenica & 7 & 16.3 \\
\hline \multirow[t]{2}{*}{5} & Prevotella buccae & 2 & 4.7 \\
\hline & Total & 43 & 100 \\
\hline & $\begin{array}{r}\text { 1. Distribution of Porphyromo } \\
\text { Species in the stud }\end{array}$ & as and $I$ & otella \\
\hline
\end{tabular}

\begin{tabular}{|c|c|c|c|c|c|c|c|c|}
\hline & Indole & Esculin & Glucose & Lactose & Sucrose & Maltose & ONPG & $\begin{array}{c}\text { Sensitivity to } \\
\text { Vancomycin (5 } \\
\mu \mathrm{g})\end{array}$ \\
\hline $\begin{array}{c}\text { Porphyromonas } \\
\text { gingivalis }\end{array}$ & + & - & - & - & - & - & + & 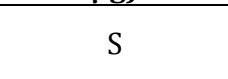 \\
\hline Porphyromonas asaccharolytica & - & & _ & _ & _ & _- & + & $\mathrm{S}$ \\
\hline Prevotella intermedia & + & +1 & + & + & + & + & + & $\mathrm{R}$ \\
\hline Prevotella melaninogenica & - & $+/$ & + & + & + & + & _ & $\mathrm{R}$ \\
\hline Prevotella buccae & + & + & + & + & + & + & + & $S$ \\
\hline
\end{tabular}

\begin{tabular}{|c|c|c|c|}
\hline Common name & Scientific name & Part used & Phytochemicals \\
\hline Betel leaf & Piper betle & Leaf & Piperol A, Piperol B \\
\hline Clove oil & Syzygium aromaticum & Flower buds & Gugenol, $\beta$-caryophyllene \\
\hline Ginger oil & Zingiber officinale & Rhizome & Geraniol, Myrcene \\
\hline Lemon grass oil & Cymbopogon flexuosus & Leaf & Mangiferin \\
\hline Mango leaves & Mangifera indica & Leaf & Myristicin, Safrole, Elemicin \\
\hline Nutmeg oil & Myristica fragrans & Fruit & Tannin, Phenol \\
\hline Pepper mint & Mentha piperita & Leaf & \\
\hline \multicolumn{2}{|r|}{ Table 3. Herbal Extracts used in the Study }
\end{tabular}

\begin{tabular}{|c|c|c|c|c|c|}
\hline Bacteria & No. & Activity & Clove Oil & Lemon Grass Oil & Nutmeg Oil \\
\hline $\begin{array}{l}\text { Porphyromonas } \\
\text { gingivalis }\end{array}$ & 20 & $\begin{array}{c}\text { PA } \\
\text { A } \\
\text { VA }\end{array}$ & $\begin{array}{l}6 \\
8 \\
6\end{array}$ & $\begin{array}{c}4 \\
10 \\
6\end{array}$ & $\begin{array}{c}6 \\
10 \\
4\end{array}$ \\
\hline Porphyromonas asaccharolytica & 5 & $\begin{array}{c}\text { PA } \\
\text { A } \\
\text { VA }\end{array}$ & $\begin{array}{l}- \\
5 \\
- \\
\end{array}$ & $\begin{array}{l}- \\
5 \\
- \\
\end{array}$ & $\begin{array}{l}- \\
5 \\
- \\
\end{array}$ \\
\hline Prevotella intermedia & 9 & $\begin{array}{c}\text { PA } \\
\text { A } \\
\text { VA }\end{array}$ & $\begin{array}{l}1 \\
3 \\
5\end{array}$ & $\begin{array}{l}4 \\
5 \\
-\end{array}$ & $\begin{array}{l}1 \\
3 \\
5\end{array}$ \\
\hline Prevotella melaninogenica & 7 & $\begin{array}{c}\text { PA } \\
\text { A } \\
\text { VA }\end{array}$ & $\begin{array}{l}2 \\
2 \\
3 \\
\end{array}$ & $\begin{array}{l}2 \\
5 \\
- \\
\end{array}$ & $\begin{array}{l}2 \\
4 \\
1 \\
\end{array}$ \\
\hline Prevotella buccae & 2 & $\begin{array}{c}\text { PA } \\
\text { A } \\
\text { VA }\end{array}$ & $\begin{array}{l}- \\
- \\
2\end{array}$ & $\begin{array}{l}- \\
2 \\
-\end{array}$ & $\begin{array}{l}- \\
2 \\
-\end{array}$ \\
\hline
\end{tabular}

PA - Partially active (Zone diameter 9-12 mm)

A - Active (Zone diameter 13-18 mm)

VA - Very active (Zone diameter $>18 \mathrm{~mm}$ ) (Alves et.al Ref 22.) 


\begin{tabular}{|c|c|c|c|c|c|c|}
\hline $\begin{array}{l}\text { Bacteria \& Numbers } \\
\text { Tested }\end{array}$ & No. & Activity & $\begin{array}{l}\text { Betel Leaf } \\
\text { Extract }\end{array}$ & $\begin{array}{l}\text { Ginger } \\
\text { Oil }\end{array}$ & $\begin{array}{l}\text { Mango Leaves } \\
\text { Extract }\end{array}$ & Peppermint oil \\
\hline $\begin{array}{l}\text { Porphyromonas } \\
\text { gingivalis }\end{array}$ & 20 & $\begin{array}{c}\text { I } \\
\text { PA } \\
\text { A }\end{array}$ & $\begin{array}{c}20 \\
- \\
-\end{array}$ & $\begin{array}{c}16 \\
4 \\
- \\
\end{array}$ & $\begin{array}{c}18 \\
2 \\
-\end{array}$ & $\begin{array}{c}16 \\
2 \\
2\end{array}$ \\
\hline $\begin{array}{l}\text { Porphyromonas } \\
\text { asaccharolytica }\end{array}$ & 5 & $\begin{array}{c}\text { I } \\
\text { PA } \\
\text { A }\end{array}$ & $\begin{array}{l}5 \\
- \\
-\end{array}$ & $\begin{array}{l}5 \\
- \\
-\end{array}$ & $\begin{array}{l}5 \\
- \\
-\end{array}$ & $\begin{array}{l}5 \\
- \\
-\end{array}$ \\
\hline $\begin{array}{l}\text { Prevotella } \\
\text { intermedia }\end{array}$ & 9 & $\begin{array}{c}\text { I } \\
\text { PA } \\
\text { A }\end{array}$ & $\begin{array}{l}9 \\
- \\
- \\
\end{array}$ & $\begin{array}{l}7 \\
2 \\
- \\
\end{array}$ & $\begin{array}{l}5 \\
2 \\
2 \\
\end{array}$ & $\begin{array}{l}5 \\
2 \\
2 \\
\end{array}$ \\
\hline $\begin{array}{c}\text { Prevotella } \\
\text { melaninogenica }\end{array}$ & 7 & $\begin{array}{c}\mathrm{I} \\
\mathrm{PA} \\
\mathrm{A}\end{array}$ & $\begin{array}{l}7 \\
- \\
- \\
\end{array}$ & $\begin{array}{l}5 \\
2 \\
- \\
\end{array}$ & $\begin{array}{l}6 \\
1 \\
- \\
\end{array}$ & $\begin{array}{l}5 \\
2 \\
- \\
\end{array}$ \\
\hline $\begin{array}{l}\text { Prevotella } \\
\text { buccae }\end{array}$ & 2 & $\begin{array}{c}\mathrm{I} \\
\mathrm{PA} \\
\mathrm{A}\end{array}$ & $\begin{array}{l}2 \\
- \\
-\end{array}$ & $\begin{array}{l}2 \\
- \\
-\end{array}$ & $\begin{array}{l}- \\
2 \\
-\end{array}$ & $\begin{array}{l}- \\
2 \\
-\end{array}$ \\
\hline & \multicolumn{6}{|c|}{$\begin{array}{c}\text { Table 5. Antimicrobial Activity of Herbal Extracts showing Variable Activity against } \\
\text { Porphyromonas-Prevotella Group }\end{array}$} \\
\hline
\end{tabular}

I -Inactive- (Zone diameter- less than $9 \mathrm{~mm}$ )

PA- Partially Active (Zone diameter -9-12 mm)

A- Active (Zone diameter - 13-17 mm) (Alves et.al Ref 22.)

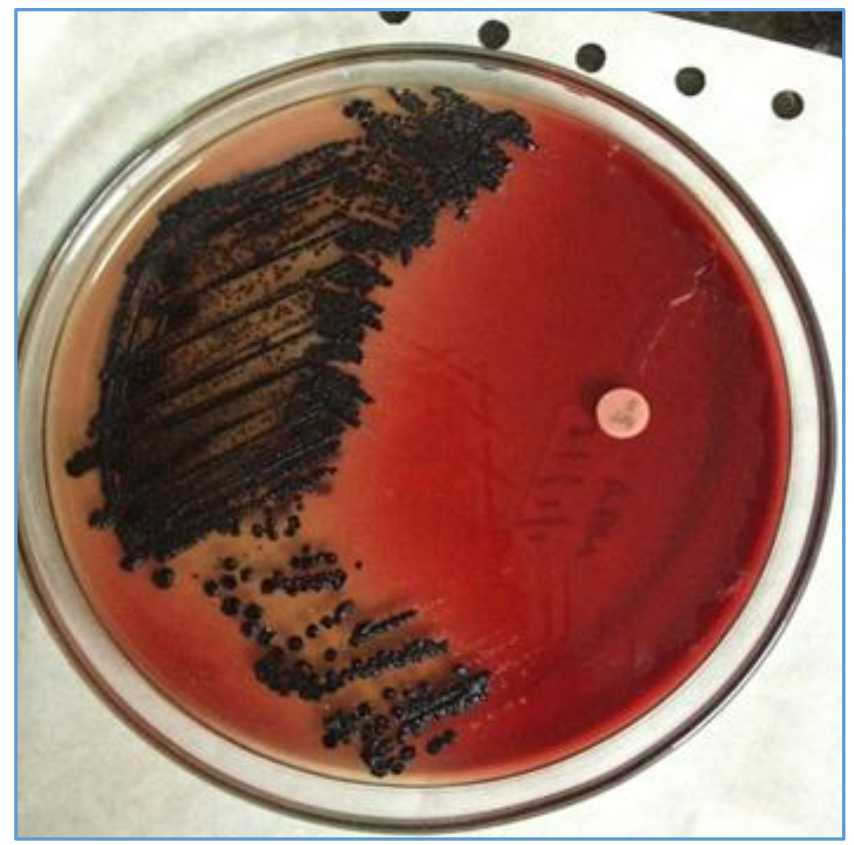

\section{Black Pigmented Colonies of Porphyromonas gingivalis on Laked Blood Agar, showing Sensitivity to Metronidazole Disc}

\section{DISCUSSION}

Porphyromonas-Prevotella group, a main component of oral flora, is a major pathogen of periodontitis. They can disseminate from oral cavity to initiate numerous invasive non-oral infections also. A total of 43 isolates included in the study were obtained from orodental infections. Saliva, paper points and plaque samples were subjected for the isolation. Majority of the isolates were Porphyromonas gingivalis (46.5\%), one of the components of red complex. Reports are hardly available from India regarding the isolation and characterisation of Porphyromonas and Prevotella group due to the complexity of the anaerobic culture techniques.

All the 43 strains of Porphyromonas-Prevotella groups in this study were speciated by biochemical characterisation.
Major isolate was P. gingivalis (20 isolates), followed by Prevotella intermedia ( 9 isolates). Two non-pigmented species were identified as Prevotella buccae. The pathogenic potential of $P$. gingivalis was reported by previous investigators. $(3,4)$

The increasing antibiotic resistance among the oral pathogenesis is a matter of concern among the dentists. Plant-derived medicines have made large contributions to human health and wellbeing in some clinical settings. Phytomedicines have shown great promise in the treatment of various infections. The medicinal properties of plants have been investigated, in the light of recent scientific developments, throughout the world due to their potent pharmacological activities and economic feasibility.(23) It has been reported that plants either contain antimicrobials that can act on pathogens or can operate in synergy with antibiotics or possess compounds that are able to sensitise the pathogen to an ineffective antibiotic. $(23,24)$ This provides the rationale for research into the potential outcome of employing plant-derived essential oils as a treatment option.

In the present study, we determined the antimicrobial efficacy of herbal extracts such as bêtel leaf, mango leaves and essential oils of clove, ginger, lemongrass, nutmeg and peppermint. Various parts of all these plants were employed in the treatment of dental problems from time immemorial. Among these Clove oil, lemongrass oil, nutmeg oil showed good antimicrobial activity, in vitro, against Porphyromonas and Prevotella group. Clove oil exhibited the best result among all, by disc diffusion test.

Clove oil possesses many medicinal properties and was used as an analgesic in dental practice from time immemorial. Its major components like eugenol and $\beta$-caryophyllene were found to have good antibacterial activity against various cariogenic organisms and anaerobic periodontal pathogens as shown in the literature.(25) Reports demonstrating antibacterial action of clove oil on Porphyromonas and Prevotella are lacking from India, except a study which showed good antimicrobial activity of aqueous extract of clove against single clinical isolate of Porphyromonas gingivalis by agar well diffusion assay.(26) Another study done 
by Nzeako B C suggested that clove oil also possess antimicrobial activity against aerobic bacteria with a concentration of $0.2 \%$ clove oil.(27)

Lemon grass belongs to the family Poaceae. Out of 500 described species, two species - Cymbopogon citratus and Cymbopogon flexuosus- are generally called as lemon grass. The essential oil, extracted from leaves of Cymbopogon flexuosus, is used to cure various ailments like cough, cold, haemoptysis, rheumatism, lumbago, digestive problems, vomiting, etc. as seen in the literature. It was also used as mouth wash for toothache and swollen gums. Many reports are available on the antibacterial activity of lemon grass oil against various aerobes and fungi.(28) Reports on antibacterial activity of lemon grass oil exclusively against Porphyromonas and Prevotella are lacking from Indian subcontinent. Few authors have reported the efficacy of lemon grass mouth rinse on Porphyromonas and Prevotella along with other oral bacteria by using disc diffusion method and broth dilution assay.(29)

Medicinal use of Myristica fragrans (Nutmeg) is known to mankind since antiquity. Main constituents of nutmeg have been found to be Myristicin, safrole, elemicin, myristic acid, etc. and it is proved to have antimicrobial, antidepressant, antioxidant, memory enhancing properties. Shafiei Zaleha et al reported that the antimicrobial activity of nutmeg oil against oral pathogens by using agar well diffusion and broth dilution assay and proved that the both ethyl acetate and ethanol crude extracts from flesh, seed mace and oil from Myristica fragrans exhibited good potential against oral pathogens. ${ }^{(30)}$ In the present study also, nutmeg oil was found to be very active against Porphyromonas and Prevotella.

\section{CONCLUSION}

Porphyromonas-Prevotella group is a significant pathogen causing a variety of orodental infections. Various herbal extracts have exhibited antimicrobial activity against these potential pathogens. The scope for developing these extracts into an alternative drug in conjunction with other antibiotics for treatment of drug resistance infections may be considered. However, further pharmacokinetic and pharmacodynamic tests are needed for routine clinical use. This study also justifies the incorporation of some of these herbals in the modern tooth pastes.

\section{REFERENCES}

[1] Newman MG. Goodman AD. Oral and dental infections. In: T.B. anaerobic infections in humans. Chapter 11. Finegold SM, George WL (eds). Academic press inc: Harcourt brace Jovanovich pub. San Diego California 1989:234-62.

[2] Winn WC, Allen SD, Janda WM, et al. The anaerobic bacteria. In: Koneman's colour atlas and text book of diagnostic microbiology. $6^{\text {th }}$ edn. Chapter 16. Lippincott William \& Wilkins Publishers, Philadelphia, USA 2006:877-944.

[3] Mysak J, Podzimek S, Sommerova P, et al. Porphyromonas gingivalis: major periodontopathic pathogen overview. J Immunol Res 2014;2014:476068.

[4] Griffen AL, Becker RM, Lyons SR, et al. Prevalence of Porphyromonas gingivalis and periodontal health status. J Clin Microbiol 1998;36(11):3239-42.
[5] Bodet C, Chandad F, Grenier D. Pathogenic potential of Porphyromonas gingivalis, Treponema denticola and Tannerella forsythia, the red bacterial complex associated with periodontitis. Pathologie Biologie 2007;55(3-4):154-62.

[6] Brook I. The role of anaerobic bacteria in bacteremia. Anaerobe 2010;16(3):183 -9.

[7] Nord CE. The role of anaerobic bacteria in recurrent episodes of sinusitis and tonsillitis. Clin infect Dis 1995;20(6):1512-24.

[8] Brook I. Anaerobic bacteria in upper respiratory tract and head and neck infection: microbiology and treatment. Anaerobe 2012;18(2):214-20.

[9] Bartlett JG. How important are anaerobic bacteria in aspiration pneumonia: when should they be treated and what is optimal therapy. Infect Dis Clin North Am 2013;27(1):149-55.

[10] Fosse T, Madinier I, Hannoun L, et al. High prevalence of cfxA beta-lactamase in aminopenicillin-resistant Prevotella strains isolated from periodontal pockets. Oral Microbiol Immunol 2002;17(2):85-8.

[11] Bidault P, Chandad F, Grenier D. Risk of bacterial resistance associated with systemic antibiotic therapy in periodontology. J Canad Dent Assoc 2007;73(8):721-5.

[12] Andres MT, Chung WO, Roberts MC, et al. Antimicrobial susceptibilities of Porphyromonas gingivalis, Prevotella intermedia, and Prevotella nigrescens spp. isolated in Spain. Antimicrob Agents Chemother 1998;42(11):3022-3.

[13] Emilson CG. Potential efficacy of chlorhexidine against mutans streptococci and human dental caries. J Dent Res 1994;73(3):682-91.

[14] Addy M, Moran J. Mechanism of stain formation on teeth, in particular associated with metal ions and antiseptics. Advance Dental Research 1995;9(4):4506.

[15] Palombo EA. Traditional medicinal plant extracts and natural products with activity against oral bacteria: potential application in the prevention and treatment of oral diseases. Evid Based Complement Alternat Med 2011;2011:680354.

[16] Cowan MM. Plant products as antimicrobial agents. Clin Microbiol Rev 1999;12(4):564-82.

[17] Almas K. The effect of Salvadora persica extract (Miswak) and chlorhexidine gluconate on human dentin: a SEM study. J Contemp Dent Prac 2002;3(3):27-35.

[18] Alviano WS, Alviano DS, Diniz CG, et al. In vitro antioxidant potential of medicinal plant extracts and their activities against oral bacteria based on Brazilian folk medicine. Arch Oral Biol 2008;53(6):545-52.

[19] Syed SA, Loesche WJ. Survival of human dental plaque flora in various transport media. Appl Microbiol 1972;24(4):638-44.

[20] Somer HRJ, Summanen P, Citron DM, et al. Wadsworth-KTL anaerobic bacteriology manual. $6^{\text {th }}$ edn. Star Publishing Company, Belmont, California, 2002.

[21] Willis TA. Anaerobic bacteriology clinical \& laboratory practice. $3^{\text {rd }}$ edn. Butterworths (Pub), Boston 1977. 
[22] Alves TM, Silva AF, Brandao M, et al. Biological screening of Brazilian medicinal plants. Mem Ins Oswaldo Cruz 2000;95(3):367-73.

[23] Dahiya P, Purkayastha S. Phytochemical screening and antimicrobial activity of some medicinal plants against multi-drug resistant bacteria from clinical isolates. Indian J Pharm Sci 2012;74(5):443-50.

[24] Maizura M, Fazilah A, Norziah MH, et al. Antimicrobial activity and mechanical properties of partially hydrolyzed sago starch-alginate edible film containing lemongrass oil. J Food Sci 2007;72(6):C324-30.

[25] Cai L, Wu CD. Compounds from Syzygium aromaticum possessing growth inhibitory activity against oral pathogens. J Nat Prod 1996;59(10):987-90.

[26] Mohammad $\mathrm{HH}$, in vitro antibacterial activity of propolis, alum, Miswak, green and black tea extracts against Porphyromonas gingivalis isolated from periodontitis patients in Hilla city Iraq. J Phytomed \& Clin Therapeut 2002;2:140-8.
[27] Nzeako BC, Al-Kharousi ZS, Al-Mahrooqui $\quad$ Z. Antimicrobial activities of clove and thyme extracts. Med J 2006;6(1):33-9.

[28] Inouye S, Takizawa T, Yamaguchi H. Antimicrobial activity of essential oils and their major constituents against respiratory tract pathogens by gaseous contact. J Antimicro Chemother 2001;47(5):565-73.

[29] Satthanakul P, Taweechaisupapong S, Paphangkorakit J, et al. Antimicrobial effect of lemon grass oil against oral malodour microorganisms and the pilot study of safety and efficacy of lemongrass mouth rinse on oral malodour. J Appl Microbiol 2015;118(1):11-7.

[30] Zaleha S, Shuhairi NN, Latip J, et al. Antibacterial activity of Myristica fragrans against oral pathogens. Academic J 2012:7. 